\title{
PENGARUH KUALITAS LAYANAN BERBASIS TEHNOLOGI INFORMASI (TI) TERHADAP KEPUASAN PELANGGAN PADA PERUSAHAAN DAERAH AIR MINUM (PDAM) KABUPATEN BONDOWOSO
}

\author{
Fathorrasi $^{1}$, Suwignyo Widagdo ${ }^{2}$, Yuniorita Endah Handayani ${ }^{3}$ \\ Email : Fathorrasi73@gmail.com¹, Suwignyo@stie-mandala.ac.id², \\ yuniorita@stie-mandala.ac.id ${ }^{3}$
}

\begin{abstract}
Entities both business and public, will improve the quality of service with dimensions that are well applied so that it becomes the key to success in the business and public sector. Good quality service will provide customer satisfaction. Customer satisfaction is the key to business success. Related research to discuss and analyze the effect of services quality based on Information Technology to customer satisfaction of the Regional Water Supply Company of Bondowoso Regency.

The data used in this study are primary data obtained through questionnaires. The population of this study is active customers in the service area of the Regional Water Supply Company of Bondowoso Regency with a total sample of 100 people and accidental sampling. For data analysis, the authors used multiple linear regression analysis.

Based on the results of the analysis, it can be stated that simultaneously Information Technology (IT) based service quality variables consisting of Reliability, Tangible, Assurance, Empaty and Responsiveness affect customer satisfaction in the Regional Water Supply Company (PDAM) of Bondowoso Regency. Partially, the variable quality of service based on Information Technology (IT) consisting of Reliability, Tangible, Assurance, and Responsiveness affects customer satisfaction in the Regional Water Supply Company (PDAM) of Bondowoso Regency. Where as the variable quality of service based on Information Technology (IT) measured by Empathy partially did not affect customer satisfaction in the Regional Water Supply Company (PDAM) of Bondowoso Regency. Variables in service quality based on Information Technology (IT) as measured by reliability are the dominant variables in influencing the level of customer satisfaction in the Regional Water Supply Company (PDAM) of Bondowoso Regency.
\end{abstract}

Keywords: Service Quality, Reliability, Tangible, Assurance, Empaty Responsiveness, and Customer Satisfaction 


\section{Pendahuluan}

Dalam rangka mengetahui kualitas layanan telah diberikan secara bermutu oleh Perusahaan Daerah Air Minum (PDAM) Kabupaten Bondowoso indicator yang dapat dilihat adalah kepuasan yang dirasakan oleh pelanggan. Kepuasan pelanggan merupakan hasil penilaian terhadap kualitas layanan Perusahaan Daerah Air Minum (PDAM) Kabupaten Bondowoso yang dibandingkan dengan harapan pelanggan. Oleh karena itu kualitas layanan menjadi salah satu faktor penting agar dapat memberikan kepuasan kepada pelanggan.

Perusahaan Daerah Air Minum (PDAM) Kabupaten Bondowoso dalam pelaksanaan pelayanan kepada masyarakat tentunya menghadapai beberapa kendala berupa gangguan pelayanan atau distribusi air ke pelanggan, menurunnya debit air atau secara administrasi berupa informasi tentang cara mendaftar sebagai calon pelanggan, informasi tagihan rekening dan pengaduan pelanggan.

Masalah tersebut bisa mempengaruhi tingkat kepuasan pelanggan,sehingga mulai awal tahun 2012 dilaksanakan penambahan sarana peningkatan kualitas layanan berbasis Tehnologi Informasi (TI) pada proses menjadi pelanggan baru, pembacaan water meter, info tagihan rekening, pembayaran rekening online dan laporan gangguan, dengan harapan kepuasan pelanggan semakin bertambah terhadap kinerja Perusahaan Daerah Air Minum (PDAM) Bondowoso.

Efektifitas sesudah penggunaan Tehnologi Informasi (TI) pada layanan di Perusahaan Daerah Air Minum (PDAM) Kabupaten Bondowoso tergambar seperti dibawah ini :

1. Pelayanan pendaftaran untuk menjadi pelanggan semakin singkat, yang semula minimal 7 hari kerja menjadi 3 hari kerja sesuai SOP PDAM Bondowoso.

2. Pembacaan water meter semakin akurat karena petugas harus mengambil gambar dan dikirim ke server pusat.

3. Informasi tagihan rekening akan selalu dikirim melalui SMS kepada pelanggan, sehingga mempermudah pada saat di loket pembayaran.

4.Bagi pelanggan yang ke luar kota dan bertepatan dengan hari terakhir 
pembayaran akan mudah dilaksanakan di bank atau PPOB yang bekerja sama dengan PDAM Bondowoso.

5. Laporan gangguan bisa dilaksanakan dengan cepat melalui telpon, SMS, dan WA untuk selanjutnya ditindak lanjuti.

Berdasarkan uraian tersebut maka dalam penelitian ini dirumuskan sebagai berikut :

a. Kualitas layanan berbasis Tehnologi Informasi (TI) yang diukur dengan Reliability, tangible, Assurance, Empaty dan Responsi berpengaruh terhadap kepuasan pelanggan.

b. Manakah di antara kualitas layanan berbasis Tehnologi Informasi (TI) yang dominan berpengaruh terhadap kepuasan pelanggan ?

Agar dapat mencapai target sesuai maksud dan latar belakang penelitian, maka dalam pembahasan dibatasi pada :

1. Kualitas layanan yang berbasis Tehnologi Informasi (TI) pada proses menjadi pelanggan baru, pembacaan water meter, info tagihan rekening, pembayaran rekening online dan laporan gangguan di Perusahaan Daerah Air Minum (PDAM) Kabupaten Bondowoso,

2. Responden adalah pelanggan aktif Perusahaan Daerah Air Minum (PDAM) Kabupaten Bondowoso,

3. Variabel dari kualitas layanan yang dianalisis adalah :

a. Reliability (handal),

b. Tangible (bukti fisik),

c. Assurance (keyakinan),

d. Empaty (empati) dan

e. Responsivennes (tanggap).

\section{Tinjauan Pustaka}

\subsection{Penelitian Terdahulu}

Beberapa penelitian terdahulu yang menjadi rujukan untuk menentukan langkah -langkah yang perlu dilakukan dalam penelitian ini adalah : 
Syahri dan Rohamah (2017), untuk mengetahui dan menganilisis pengaruh kwalitas layanan terhadap kepuasan pelanggan PT. Sucofindo Batam. Hasilnya menunjukkan ada pengaruh kualitas layanan secara simultan terhadap kepuasan pelanggan dan variable empathy adalah variable paling dominan berpengaruh terhadap kepuasan pelanggan.

Silvia dan Kartika (2017), untuk mengetahui dan menganalisa persepsi dokter Rumah Sakit Hernia Bogor terhadap kualitas layanan BPJS kesehatan dan tingkat kepuasan program jaminan kesehatan nasional serta menganalisis pengaruh kualitas pelayanan BPJS Kesehatan terhadap kepuasan Dokter RS Hernia Bogor. Hasilnya menunjukkan H0 ditolak, artinya secara simultan kualitas pelayanan BPJS Kesehatan berpengaruh terhadap kepuasan Dokter Hernia Bogor.

Effendi dan Lili (2016), untuk mengetahui pengaruh kualitas layanan terhadap kepuasan pelanggan yang diukur dengan keandalan, jaminan, bukti fisik, empati dan daya tanggap baik secara bersama - sama atau sebagian pada JNE cabang Bandung, instrument analisis yang digunakan adalah analisis regresi berganda. Hasil penelitian terdapat pengaruh secara simultan (bersama - sama) kualitas pelayanan yang terdiri dari keandalan, jaminan, bukti fisik, empati dan daya tanggap terhadap kepuasan pelanggan. Namun secara parsial pengaruh kualitas pelayanan kualitas pelayanan berupa keandalan, jaminan, bukti fisik, dan daya tanggap tidak berpengaruh. Sedangkan empati mempunyai pengaruh yang signifikan terhadap kepuasan pelanggan.

Ali dan Ali (2015), untuk mengethaui dan menganalisa hubungan antara kualitas layanan yang diukur keandalan, jaminan, bukti fisik, empati dan daya tanggap terhadap kepuasan pelanggan di Bank Islam Pakistan, instrument alas analisis menggunakan confirmatory factor analysis (CFA) dan structural equation modeling (SEM) dengan hasil penelitian ada pengaruh baik secara simultan dan parsial teradap kepuasan pelangga dan tangible adalah variable yang paling dominan.

Ishak Awaludin dan M Setiawan (2012), untuk mengetahui pengaruh kualitas layanan terhadap kepuasan, nilai, kepercayaan dan loyalitas pelanggan rumah tangga pada Perusahaan Daerah Air Minum Kota Kendari. Metode 
penelitian adalah menggunakan statistik Structural Equation Modeling (SEM) dengan bantuan program. Hasil penelitian terdapat Peningkatan layanan yang baik di Perusahaan Daerah Air Minum (PDAM) Kota Kendari akan meningktkan kepuasan pelanggan dan selanjutnya meningktkan loyalitas pelanggan, bila kepuasan tersebut menimbukan kepercayaan. Peningkatan loyalitas pelanggan juga dapat dicapai bila layanan yang diberikan mampu meningktkan nilai pelanggan. Disamping itu dalam penelitian ini terbukti bahwa kepercayaan berperan sebagai mediasi antara kepuasan pelanggan dengan loyalitas pelanggan dan antara nilai pelanggan dengan loyalitas pelanggan.

Yang membedakan antara penelitian terdahulu dengan penelitian ini adalah penggunaaan variabel kualitas layanan berbasis Tehnologi Informasi (TI) pada indicator layanan pemasangan sambungan baru, pembacaan water meter, informasi tagihan, pembayaran rekening online dan pengaduan pelanggan.

\subsection{Kajian Teori}

\subsubsection{Pengertian Kualitas Layanan}

Dewasa ini konsep kualitas telah menjadi faktor yang sangat dominan terhadap keberhasilan suatu organisasi. Kualitas menjadi pedoman utama dalam pengembangan dan keberhasilan implementasi program-program manajerial dan kerekayasaan untuk mewujudkan tujuan-tujuan bisnis yang utama.

Secara etimologi tidak mudah mendefinisikan atau memberikan pengertian mengenai kualitas. Namun demikian ada beberapa definisi umum yang diberikan oleh beberapa pakar kualitas. Menurut Tjiptono dan Chandra (2004; 195) kualitas bisa diartikan sebagai upaya pemenuhan suatu atau membuat sesuatu memadai. Taguchi (dalam Tjiptono, 2004 : 12) menjelaskan kualitas adalah kerugian yang ditimbulkan oleh suatu produk bagi masyarakat setelah produk tersebut dikirim, selain kerugian-kerugian yang disebabkan fungsi intrinsik produk.

William E Doming (dalam Tjiptono, 2004 : 48) menjelaskan "Kualitas merupakan suatu tingkat yang dapat diprediksi dari keseragaman dan ketergantungan pada biaya yang rendah dan sesuai dengan pasar". 
Dalam perspektif TQM (Total Quality Management), kualitas dipandang secara lebih luas, tidak hanya aspek hasil saja yang ditekankan tetapi juga proses, lingkungan dan manusia. Goetsh dan Davis (dalam Tjiptono, 2004 : 51), menjelaskan kualitas merupakan suatu kondisi dinamis yang berhubungan dengan produk, jasa, manusia, proses dan lingkungan yang memenuhi atau melebihi harapan.

Terdapat 5 (lima) determinan kualitas layanan menurut Parasuraman seperti dikutip oleh Lupiyoadi (2006:182), yaitu :

1. Kehandalan (reliability), yaitu kemampuan untuk melaksanakan jasa yang dijanjikan dengan tepat dan terpercaya.

2. Bukti Fisik ( tangible), yaitu penampilan fasilitas fisik, peralatan, personel, dan media komunikasi.

3. Keyakinan (assurance), yaitu pengetahuan dan kesopanan pegawai serta kemampuan mereka untuk menimbulkan kepercayaan dan keyakinan atau "assurance".

4. Empati (emphaty), yaitu syarat untuk peduli, memberi perhatian pribadi bagi pelanggan.

5. Ketanggapan (responsiveness), yaitu kemampuan untuk membantu pelanggan dan memberikan jasa dengan cepat.

\subsubsection{Pengertian Kepuasan Pelanggan}

Menurut Tse dan Wilton (dalam Tjiptono, 2004 : 146) disebutkan bahwa kepuasan atau ketidakpuasan pelanggan adalah respon pelanggan terhadap evaluasi ketidaksesuaian yang dirasakan antara harapan sebelumnya dan kinerja aktual produk setelah pemakaiannya. Kepuasan pelanggan merupakan fungsi dari harapan dan kinerja.

Oliver (dalam Tjiptono, 2004 : 146) memberikan pendapat bahwa kepuasan keseluruhan ditentukan oleh ketidaksesuaian harapa yang merupakan perbandingan antara kinerja yang dirasakan dengan harapan.

Kotler (dalam Tjiptono, $2004: 147$ ) memberikan definisi kepuasan pelanggan sebagai perasaan senang atau kecewa seseorang yang berasal dari 
perbandingan antara kesannya terhadap kinerja (atau hasil) suatu produk dan harapan-harapannya.

Definisi tersebut di atas dapat dijabarkan bahwa kepuasan merupakan fungsi dari kesan kinerja dan harapan. Apabila kinerja berada di bawah harapan, pelanggan tidak puas, sebaliknya apabila kinerja memenuhi harapan, pelanggan puas dan apabila kinerja melebihi harapan, pelanggan amat puas atau senang.

Dalam penelitian ini penulis mencoba mengaplikasikan dan menggunakan cara riset mengenai kepuasan pelanggan, sehingga nantinya secara riil dapat diketahui atribut yang memiliki hubungan kuat dengan kepuasan pelanggan. Indikator yang dipergunakan untuk mengetahui kepuasan pelanggan berupa tanggapan pelanggan yang meliputi tingkat kinerja dan tingkat harapan dari kualitas pelayanan.

Berdasarkan latar belakang, penelitia terdahulu, teori-teori tentang kualitas layanan dan kepuasan pelanggan dapat dibuat kerangka konseptual sebagai berikut :

Kerangka Konseptual

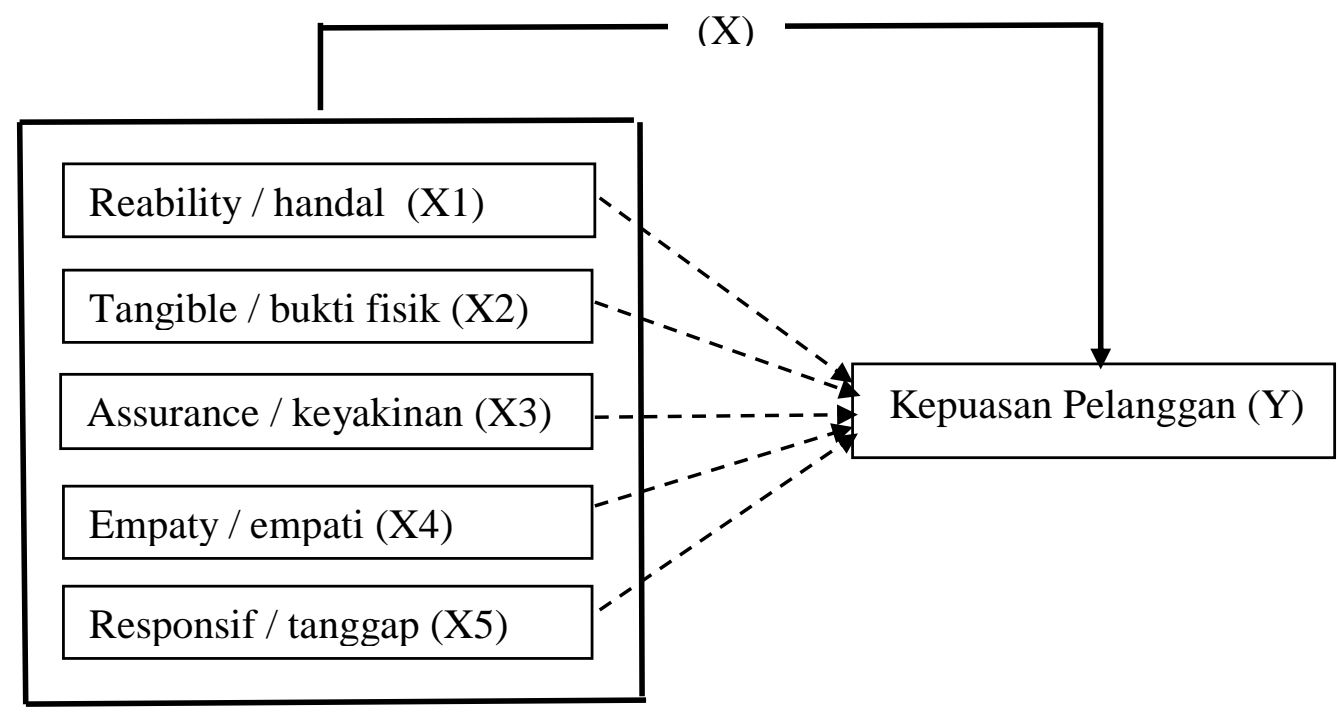

\subsection{Hipotesis}

Hipotesis menurut Nazir (2003 : 151) adalah pernyataan yang diterima secara sementara sebagai suatu kebenaran sebagaimana adanya. Dengan demikian 
hipotesis merupakan anggapan sementara yang bersifat sementara sebagai pedoman untuk mempermudah jalannya penelitian.

Adapun hipotesis dalam penelitian ini adalah sebagai berikut :

H.1 = Kualitas layanan secara simultan berpengaruh terhadap kepuasan pelanggan pada Perusahaan Daerah Air Minum (PDAM) Kabupaten Bondowoso.

H.2 = Variable kualitas layanan masing-masing secara parsial berpengaruh terhadap kepuasan pelanggan pada Perusahaan Daerah Air Minum (PDAM) Kabupaten Bondowoso.

\section{Metode Penelitian}

Penelitian ini sengaja dipilih dengan latar belakang peneliti yang bekerja sebagai karyawan Perusahaan Daerah Air Minum ( PDAM ) Kabupaten Bondowoso, beralamat kantor pusat di Jalan Mastrip No.93 A Nangkaan Bondowoso dengan obyek penelitian di masing - masing Unit Pelayanan Kecamatan (UPK) dengan populasi keseluruhan pelanggan aktif dalam wilayah layanan Perusahaan Daerah Air Minum (PDAM) Kabupaten Bondowoso.

Besarnya sampel yang diambil adalah 10 kali lebih besar dari jumlah variabel Roscoe (1975) yang dikutip Uma Sekaran (2006) yaitu jumlah Variabel $(6 \times 10)+1=61$ orang. Namun untuk lebih obyektifnya penelitian ini, sampel dibulatkan menjadi 100 orang.

Teknik pengambilan sampling yang dipergunakan dalam penelitian ini adalah accidental sampling, yaitu suatu teknik pengambilan sampel secara acak untuk memudahkan penelitian.

Adapun sebaran sampel sesuai dengan jumlah rasio, dimana jumlah pelanggan aktif dibagi jumlah sampel, $20.846: 100=208,46$ artinya setiap 1 sampel mewakili 208 orang.

Dalam penelitian ini menggunakan metode deskriftik kuantitati yang bertujuan untuk memperoleh hasil yang bersifat obyektif, tepat, dan dapat dipertanggungjawabkan kebenarannya secara ilmiah. 
Variable penelitian adalah subyek penelitian atau apa yang menjadi titik perhatian suatu penelitian (Arikunto, 1998 : 99 ) dalam penelitian ini terdiri dari : 1. Variabel bebas (independent)

Menurut Suhartanto (2014:57) bahwa variabel independen adalah variabel yang mempengaruhi variabel dependen baik positif maupun negative, Variabel independen $(\mathrm{X})$ dalam penelitian ini adalah :

a. Reliability / handal (X1),

b. Tangibel / bukti fisik (X2),

c. Assurance / keyakinan (X3),

d. Empaty / empati( X4), dan

e. Responsivenes / tanggap( X5 )

2. Variabel terikat (dependen).

Menurut Sugiono (2014:97) bahwa variabel independen merupakan variabel terpengaruh akibat dari adanya variabel independen (Y) yaitu kepuasan pelanggan.

Berdasarkan landaan teori serta identifikasi variabel yang telah dipaparkan diatas, maka perlu untuk menyusun sebuah konsep definisi operasional variabel penelitian yang dijelaskan sebagai beikut :

1.Variabel Independen atau bebas (X)

a. Kehandalan atau reliability (X1).yaitu kemampuan untuk melaksanakan jasa yang dijanjikan dengan tepat dan terpercaya.

Dimensi kehandalan (reability) pada kualitas layanan bebasis Tehnologi Informasi di PDAM Bondowoso kemudahan untuk menjadi pelanggan baru, pengerjaan dengan cepat pemasangan instalasi pelanggan baru dan pembebanan biaya yang terjangkau untuk menjadi pelanggan baru.

b. Bukti Fisik atau tangible (X2), yaitu penampilan, fasilitas fisik, peralatan, personel, dan media komunikasi.

Dimensi Bukti fisik (tangible) pada kualitas layanan bebasis Tehnologi Informasi di PDAM Bondowoso adalah datangnya petugas PDAM Bondowoso untuk membaca water meter setiap bulan, pengambilan 
gambar water meter dan pemberian informasi manakala ada kerusakan instalasi.

c. Keyakinan atau assurance (X3), yaitu pengetahuan dan kesopanan pegawai serta kemampuan mereka untuk menimbulkan kepercayaan dan keyakinan atau "assurance".

Dimensi Keyakinan (assurance) pada kualitas layanan berbasis Tehnologi Informasi di PDAM Bondowoso adalah Informasi tagihan rekening, akurasi data pemakaian air dan akurasi harga pemakaian air.

d. Empati (emphaty), yaitu syarat untuk peduli, memberi perhatian pribadi bagi pelanggan.

Dimensi empati (emphaty) pada kualitas layanan bebasis Tehnologi Informasi di PDAM Bondowoso adalah penyediaan tempat pembayaran melalui PPOB yang bekersama dengan PDAM Bondowoso, pembayaran rekening melalui ATM bank dan pembayaran online M-banking.

e. Ketanggapan (responsiveness), yaitu kemampuan untuk membantu pelanggan dan memberikan jasa dengan cepat.

Dimensi Ketanggapan (responsiveness) pada kualitas layanan bebasis Tehnologi Informasi di PDAM Bondowoso adalah respon cepat oleh petugas PDAM Bondowoso manakala ada laporan gangguan dan pengerjaan perbaikan gangguan dilaksanakan dengan baik dan tepat.

2. Variabel bebas atau independent .

Variabel bebas atau independen dalam penelitian ini adalah Variabel (Y) yaitu rasa puas terhadap kinerja PDAM Bondowoso, rasa senang menjadi pelanggan PDAM Bondowoso dan penilaian pelanggan yang menyatakan bahwa PDAM Bondowoso telah berbuat maksimal dalam melayani masyarakat Bondowoso

Teknik pengumpulan data yang dilakukan dalam penelitian ini adalah kuisioner, wawancara, observasi dan studi pustaka dengan metode analisis data sebagai berikut :

1. Uji Instrumen pengumpulan data yang terdiri dari :

a. Uji Validitas data 
Untuk menguji validitas indikator.Rumus persamaan Product Moment menurut Arikunto (1998 : 256) adalah :

$$
\operatorname{Rxy}=\frac{\mathrm{n} \Sigma x \mathrm{xy} \cdot(\Sigma \mathrm{x}) \cdot(\Sigma \mathrm{y})}{\left.\sqrt{(\mathrm{n} \Sigma \mathrm{x} 2)-(\Sigma \mathrm{x})^{2} \cdot(\mathrm{n} \Sigma \mathrm{y} 2)-(\Sigma \mathrm{y})^{2}}\right)}
$$

b. Uji Reability data

Analisa data dilakukan dengan menggunakan Rank Spearman karena skala pengukuran datanya adalah ordinal. Menurut Arikunto (1998 : 173) analisa ini digunakan untuk mengetahui hubungan antara variabel bebas (x) dengan variabel tergantung $(\mathrm{y})$ dengan rumus sebagai berikut :

$$
\mathrm{r} 11=\frac{2 \mathrm{rxy}}{1+\mathrm{rxy}}
$$

\section{Analisi Regresi Linier Berganda}

Merupakan analisis regresi linier yang digunakan untuk menguji apakah ada pengaruh dari beberapa variabel bebas terhadap variabel terikat.

Adapun garis regresinya dapat digambarkan sebagai berikut :

$$
\mathrm{Y}=\mathrm{a}+\mathrm{b} 1 \mathrm{X} 1+\mathrm{b} 2 \mathrm{X} 2+\ldots \ldots \ldots+\mathrm{ei}
$$

3. Uji Asumsi Klasik

a. Normalitas

Wiyono (2011:149) mengatakan bahwa uji normalitas berguna untuk mengetahui apakah populasi data berdistribusi normal atau tidak. Uji normalitas biasanya dilakukan untuk mengukur data yang berskala ordinal, interval, ataupun rasio. Jika analisis menggunakan metode parametrik, maka persyaratan normalitas harus terpenuhi, artinya data harus berdistribusi normal. Jika data tidak berdistribusi normal, atau jumlah sampel sedikit maka metode yang digunakan statistik non parametrik.

\section{b. Multikolinieritas}

Kuncoro (2007:98) mengatakan bahwa " pada dasarnya multikolinieritas adalah adanya suatu hubungan linear yang sempurna (mendekati sempurna) antara beberapa atau semua variabel bebas". Uji multikoliniearitas digunakan untuk 
mengetahui apakah ada atau tidaknya penyimpangan terhadap asumsi klasik (Wiyono, 2011:157).

c. Heterokedastisitas

Wiyono (2011:160) mengatakan bahwa uji heterokedastisitas digunakan untuk mengetahui ada atau tidaknya penyimpangan asumsi klasik heterokedastisitas, yaitu adanya ketidaksamaan varian dari residual untuk semua pengamatan pada model regresi.

4. Uji Hipotesis

a. Uji F test

Uji F dikenal dengan Uji serentak atau uji Model/Uji Anova, yaitu uji untuk melihat bagaimanakah pengaruh semua variabel bebasnya secara bersamasama terhadap variabel terikatnya. Pengujian ini bertujuan untuk mengetahui pengaruh variabel Reliability, Tangible, Assurance, Empaty, dan Responsiveness secara simultan terhadap kepuasan pelanggan.

$$
\mathrm{F}=\frac{\mathrm{R} 2 /(\mathrm{k}-1)}{(1-\mathrm{R} 2) /(\mathrm{n}-\mathrm{k})}
$$

\section{b. Uji t test}

Uji t dikenal dengan uji parsial, yaitu untuk menguji bagaimana pengaruh masing-masing variabel bebasnya secara sendiri-sendiri terhadap variabel terikatnya.

Dilakukan untuk mengetahui pengaruh variabel (X) terhadap variabel (Y). Menurut Sudjana (2001 : 380) uji hipotesis dirumuskan sebagai berikut :

$$
\text { t-test }=\frac{\sqrt{n-2}}{\sqrt{1-r^{2}}}
$$

\section{Sumbangan Efektif (SE)}

Sumbangan Efektif (SE) merupakan ukuran sumbangan suatu variabel independen terhadap variabel dependen dalam analisis regresi. Sumbangan Efektif (SE) dapat digunakan untuk mengetahui seberapa besar pengaruh faktor-faktor Reliability, Tangible, Assurance, Empaty, dan Responsiveness terhadap kepuasan pelanggan. Hasil perhitungan ini selanjutnya dapat digunakan untuk mengetahui 
mana diantara variabel independen yang memiliki pengaruh dominan terhadap variabel dependen.

\section{Hasil dan Pembahasan.}

4.1 Uji Insturmen Pengumpulan Data

a. Validitas

Validitas mempunyai arti sejauh mana ketepatan dan kecermatan suatu alat ukur (dalam hal ini kuesioner) melakukan fungsi ukurnya.

Tabel 4.1 Rekapitulasi Hasil Uji Validitas

\begin{tabular}{ccccc}
\hline Variabel & Item & rhitung & Sig. & Keterangan \\
\hline \multirow{3}{*}{ Reliability $(\mathrm{X} 1)$} & $\mathrm{X}_{1.1}$ & 0,886 & 0,000 & Valid \\
\cline { 2 - 5 } & $\mathrm{X}_{1.2}$ & 0,865 & 0,000 & Valid \\
\cline { 2 - 5 } Tangible $(\mathrm{X} 2)$ & $\mathrm{X}_{1.3}$ & 0,860 & 0,000 & Valid \\
\cline { 2 - 5 } & $\mathrm{X}_{2.1}$ & 0,840 & 0,000 & Valid \\
\cline { 2 - 5 } & $\mathrm{X}_{2.2}$ & 0,885 & 0,000 & Valid \\
\hline \multirow{3}{*}{ Assurance $(\mathrm{X} 3)$} & $\mathrm{X}_{2.3}$ & 0,848 & 0,000 & Valid \\
\cline { 2 - 5 } & $\mathrm{X}_{3.1}$ & 0,828 & 0,000 & Valid \\
\cline { 2 - 5 } Empaty (X4) & $\mathrm{X}_{3.2}$ & 0,825 & 0,000 & Valid \\
\cline { 2 - 5 } & $\mathrm{X}_{3.3}$ & 0,844 & 0,000 & Valid \\
\cline { 2 - 5 } & $\mathrm{X}_{4.1}$ & 0,872 & 0,000 & Valid \\
\cline { 2 - 5 } Responsiveness $(\mathrm{X} 5)$ & $\mathrm{X}_{4.2}$ & 0,820 & 0,000 & Valid \\
\cline { 2 - 5 } & $\mathrm{X}_{4.3}$ & 0,862 & 0,000 & Valid \\
\hline \multirow{2}{*}{ Kepuasan Pelanggan (Y) } & $\mathrm{X}_{5.1}$ & 0,882 & 0,000 & Valid \\
\cline { 2 - 5 } & $\mathrm{X}_{5.2}$ & 0,889 & 0,000 & Valid \\
\cline { 2 - 5 } & $\mathrm{Y}_{1}$ & 0,869 & 0,000 & Valid \\
\cline { 2 - 5 } & $\mathrm{Y}_{2}$ & 0,887 & 0,000 & Valid \\
\hline
\end{tabular}

Berdasarkan Tabel 4.8 dapat diketahui bahwa masing-masing indikator yang digunakan baik dalam variabel independen (Reliability, Tangible, Assurance, Empaty, dan Responsiveness) maupun variabel dependen (kepuasan pelanggan) mempunyai nilai probbilitas (signifikansi) $\mathrm{r}$ hitung yang lebih kecil dari 5\% (0,005). Hal ini berarti indikator-indikator yang digunakan dalam variabel penelitian ini layak atau valid digunakan sebagai pengumpul data. 
b. Uji Reliabilitas

Pengujian ini dilakukan untuk menunjukkan sejauh mana suatu hasil pengukuran relatif konsisten. Suatu pertanyaan yang baik adalah pertanyaan yang jelas mudah dipahami dan memiliki interpretasi yang sama meskipun disampaikan kepada responden yang berbeda dan waktu yang berlainan. Hasil pengujian reliabilitas adalah sebagai berikut:

Tabel 4.2 Hasil Uji Reliabilitas

\begin{tabular}{cccc}
\hline No & Variabel & Cronbach Alpha $(\boldsymbol{\alpha})$ & Keterangan \\
\hline 1 & $\mathrm{X}_{1}$ & 0,840 & \\
2 & $\mathrm{X}_{2}$ & 0,820 & \\
3 & $\mathrm{X}_{3}$ & 0,778 & Reliabel \\
4 & $\mathrm{X}_{4}$ & 0,810 & $\alpha>0,6$ \\
5 & $\mathrm{X}_{5}$ & 0,724 & \\
& $\mathrm{Y}$ & 0,849 & \\
\hline
\end{tabular}

Berdasarkan Tabel 4.9 dapat disimpulkan bahwa semua variabel yang digunakan dalam penelitian ini adalah reliabel, karena memiliki nilai Cronbach Alpha $(\alpha)$ lebih besar dari 0,60. Sesuai yang disyaratkan oleh Hair, et. al.(1995) bahwa varibel dikatakan reliabel jika memberikan nilai Cronbach Alpha > 0,6.

\subsection{Analisis Regresi Linier Berganda}

Pengujian regresi linear berganda berguna untuk mengetahui tingkat pengaruh variabel independen (Reliability, Tangible, Assurance, Empaty, dan Responsiveness) terhadap variabel dependen (kepuasan pelanggan). Berdasarkan pengujian diperoleh hasil yang dapat disajikan dalam tabel berikut.

Tabel 4.3 Hasil Perhitungan Regresi Linear Berganda

\begin{tabular}{|c|c|c|c|c|}
\hline Variabel & Koef. Regresi & $t_{\text {hitung }}$ & $\mathrm{t}_{\text {tabel }}$ & Sig. \\
\hline Konstanta & $-0,513$ & $-0,522$ & 1,983 & 0,603 \\
\hline $\mathrm{X}_{1}$ & 0,277 & 2,995 & 1,983 & 0,004 \\
\hline $\mathrm{X}_{2}$ & 0,194 & 2,393 & 1,983 & 0,019 \\
\hline$X_{3}$ & 0,179 & 2,173 & 1,983 & 0,032 \\
\hline $\mathrm{X}_{4}$ & 0,095 & 1,051 & 1,983 & 0,296 \\
\hline $\mathrm{X}_{5}$ & 0,515 & 3,463 & 1,983 & 0,001 \\
\hline & \multicolumn{2}{|c|}{$\mathrm{R}(R$ Square $)$} & \multicolumn{2}{|c|}{$0,800(0,640)$} \\
\hline & \multicolumn{2}{|c|}{$F_{\text {hitung }}($ Sig $)$} & \multicolumn{2}{|c|}{$33,358(0,000)$} \\
\hline & \multicolumn{2}{|l|}{$\mathrm{N}$} & \multicolumn{2}{|c|}{100} \\
\hline
\end{tabular}


Berdasarkan hasil tersebut dapat diperoleh persamaan regresi linier berganda sebagai berikut:

$\mathrm{Y}=-0,513+0,277 \mathrm{X} 1+0,194 \mathrm{X} 2+0,179 \mathrm{X} 3+0,095 \mathrm{X} 4+0,515 \mathrm{X} 4+\mathrm{e}$

\subsection{Uji Asumsi Klasik}

a. Uji Normalitas

Uji normalitas bertujuan untuk menguji apakah dalam model regresi, variabel dependen dan independen keduanya mempunyai distribusi normal atau tidak.

Tabel 4.4 Hasil Uji Normalitas

\begin{tabular}{cccc}
\hline Variabel & Kolmogorov - Smirnov & Sig & Keterangan \\
\hline Abs_Res & 0,574 & 0,897 & Berdistribusi Normal \\
\hline
\end{tabular}

Berdasarkan Tabel 4.4 terlihat bahwa nilai absolute residual memiliki distribusi yang normal hal ini dilihat dari nilai signifikansi Kolmogorov-Smirnov memiliki nilai yang lebih besar dari 0,05 . Sehingga dapat dinyatakan bahwa model regresi yang diperoleh telah memenuhi asumsi normalitas model.

b.Uji Multikolinearitas

Multikolinearitas berarti terjadi interkorelasi antar variabel bebas yang menunjukkan adanya lebih dari satu hubungan linier yang signifikan.

Tabel 4.5 Collinearity Statistic

\begin{tabular}{ccc}
\hline Variabel & VIF & Keterangan \\
\hline $\mathrm{X}_{1}$ & 2,308 & Tidak ada multikolinearitas \\
$\mathrm{X}_{2}$ & 1,776 & Tidak ada multikolinearitas \\
$\mathrm{X}_{3}$ & 1,449 & Tidak ada multikolinearitas \\
$\mathrm{X}_{4}$ & 2,214 & Tidak ada multikolinearitas \\
$\mathrm{X}_{5}$ & 1,660 & Tidak ada multikolinearitas \\
\hline
\end{tabular}

Berdasarkan hasil analisis Collinearity Statistic diketahui bahwa dalam model tidak terjadi multikolinearitas. Hal ini dapat dilihat pada nilai VIF dari masing-masing variabel kurang dari 5. 


\section{c. Uji Heteroskedastisitas}

Uji ini dilakukan untuk mengetahui apakah dalam sebuah model regresi terjadi ketidaksamaan varian dari satu pengamatan ke pengamatan yang lain.

Tabel. 4.6 Hasil Pengujian Heteroskedastisitas dengan Uji Glejser

\begin{tabular}{lccc}
\hline Variabel & thitung & Sig. & Keterangan \\
\hline $\mathrm{X}_{1}$ & 0,908 & 0,366 & Non Heteroskedastisitas \\
$\mathrm{X}_{2}$ & $-1,818$ & 0,072 & Non Heteroskedastisitas \\
$\mathrm{X}_{3}$ & 0,455 & 0,455 & Non Heteroskedastisitas \\
$\mathrm{X}_{4}$ & $-0,185$ & 0,854 & Non Heteroskedastisitas \\
$\mathrm{X}_{5}$ & $-0,051$ & 0,959 & Non Heteroskedastisitas \\
\hline
\end{tabular}

Berdasarkan Tabel 4.6 diketahui bahwa t statistik menunjukkan tidak adanya pengaruh yang signifikan masing-masing variabel independen terhadap variabel dependen dimana variabel dependen yaitu ei atau error absolut, hal ini dapat dibuktikan dengan diperolehnya nilai signifikansi untuk masing-masing variabel yang lebih besar dari 0,05 $(\mathrm{P}>0,05)$. Dari hasil tersebut dapat dikatakan bahwa tidak ada gejala heteroskedastisitas.

\subsection{Uji Hipotesis}

\subsubsection{Uji F test}

Pengujian ini bertujuan untuk mengetahui pengaruh variabel Reliability, Tangible, Assurance, Empaty, dan Responsiveness secara simultan terhadap kepuasan pelanggan. Penelitian ini dilakukan dengan menggunakan tingkat signifikan 0,05. Secara bersama-sama variabel Reliability, Tangible, Assurance, Empaty, dan Responsiveness akan terbukti berpengaruh secara signifikan terhadap kepuasan pelanggan jika probabilitas $\leq 0,05$. Sebaliknya jika probabilitas $>0,05$ maka variabel Reliability, Tangible, Assurance, Empaty, dan Responsiveness tidak berpengaruh secara signifikan terhadap kepuasan pelanggan. Adapun hasil uji F secara ringkas dapat dilihat dalam Tabel 4.14.

Tabel 4.7 Hasil Perhitungan Uji F

\begin{tabular}{cccccc}
\hline $\begin{array}{c}\text { Dependent } \\
\text { Variable }\end{array}$ & $\begin{array}{c}\text { Independent } \\
\text { Variable }\end{array}$ & $R$ Square & $\mathrm{F}_{\text {hitung }}$ & $\mathrm{F}_{\text {tabel }}$ & Sig. \\
\hline $\mathrm{Y}$ & $\mathrm{X}_{1}, \mathrm{X}_{2}, \mathrm{X}_{3}, \mathrm{X}_{4}, \mathrm{X}_{5}$ & 0,640 & 33,358 & 2,31 & 0,000 \\
\hline
\end{tabular}


Berdasarkan Tabel 4.7 dapat dilihat bahwa Fhitung > Ftabel yaitu 33,358 $>$ 2,31 dan nilai probabilitas signifikansi uji $\mathrm{F}$ lebih kecil dari $0,05(0,000<0,05)$, maka variabel Reliability, Tangible, Assurance, Empaty, dan Responsiveness secara simultan berpengaruh signifikan terhadap kepuasan pelanggan, dalam hal ini H0 ditolak. Sehingga hipotesis yang menyatakan bahwa secara simultan variabel kualitas layanan berbasis Tehnologi Informasi (TI) yang terdiri dari Reliability, Tangible, Assurance, Empaty dan Responsiveness berpengaruh terhadap kepuasan pelanggan pada Perusahaan Daerah Air Minum (PDAM) Kabupaten Bondowoso terbukti kebenarannya atau H1 diterima.

\subsubsection{Hasil Uji t test}

Pengujian ini dimaksudkan untuk mengetahui pengaruh masing-masing variabel independen terhadap variabel dependen. Caranya adalah dengan membandingkan nilai statistik thitung dengan nilai statistik ttabel dengan tingkat signifikan $(\alpha)$ yang digunakan yaitu 5\%. Masing-masing variabel bebas dikatakan mempunyai pengaruh yang signifikan (nyata) apabila thitung lebih besar dari ttabel atau apabila probabilitas $<5 \%(\alpha)$.

Hasil perhitungan uji $\mathrm{t}$ dengan menggunakan program SPSS for Windows dapat dilihat pada Tabel 4.3. Berdasarkan tabel tersebut dapat diketahui besarnya pengaruh masing-masing variabel bebas terhadap variabel terikat sebagai berikut:

1. Pengaruh variabel reliability (X1) terhadap kepuasan pelanggan (Y) Berdasarkan Tabel 43 dapat diketahui bahwa thitung > ttabel yaitu 2,995> 1,983. Karena thitung lebih besar dari ttabel, maka H0 ditolak, berarti secara parsial variabel reliability (X1) mempunyai pengaruh signifikan terhadap kepuasan pelanggan pada Perusahaan Daerah Air Minum (PDAM) Kabupaten Bondowoso (Y). Sehingga, hipotesis yang menyatakan bahwa secara parsial variabel kualitas layanan berbasis Tehnologi Informasi (TI) yang diukur dengan reliability berpengaruh terhadap kepuasan pelanggan pada Perusahaan Daerah Air Minum (PDAM) Kabupaten Bondowoso terbukti kebenarannya atau H2.1 diterima. 
2. Pengaruh variabel tangible (X2) terhadap kepuasan pelanggan (Y) Berdasarkan Tabel 4.3 dapat diketahui bahwa thitung > ttabel yaitu 2,393> 1,983. Karena thitung lebih besar dari ttabel, maka H0 ditolak, berarti secara parsial variabel tangible (X2) mempunyai pengaruh signifikan terhadap kepuasan pelanggan pada Perusahaan Daerah Aor Minum (PDAM) Kabupaten Bondowoso (Y). Sehingga, hipotesis yang menyatakan bahwa secara parsial variabel kualitas layanan berbasis Tehnologi Informasi (TI) yang diukur dengan tangible berpengaruh terhadap kepuasan pelanggan pada Perusahaan Daerah Air Minum (PDAM) Kabupaten Bondowoso terbukti kebenarannya atau H2.2 diterima.

3. Pengaruh variabel assurance (X3) terhadap kepuasan pelanggan (Y) Berdasarkan Tabel 4.3 dapat diketahui bahwa thitung > ttabel yaitu 2,173> 1,983. Karena thitung lebih besar dari ttabel, maka H0 ditolak, berarti secara parsial variabel assurance (X3) mempunyai pengaruh signifikan terhadap kepuasan pelanggan pada Perusahaan Daerah Air MInum (PDAM) Kabupaten Bondowoso (Y). Sehingga, hipotesis yang menyatakan bahwa secara parsial variabel kualitas layanan berbasis Tehnologi Informasi (TI) yang diukur dengan assurance berpengaruh terhadap kepuasan pelanggan pada Perusahaan Daerah Air Minum (PDAM) Kabupaten Bondowoso terbukti kebenarannya atau H2.3 diterima.

4. Pengaruh variabel empaty (X4) terhadap kepuasan pelanggan (Y)

Berdasarkan Tabel 4.3 dapat diketahui bahwa thitung < ttabel yaitu 1,051 < 1,983. Karena thitung lebih kecil dari ttabel, maka H0 diterima, berarti secara parsial variabel empaty (X4) mempunyai pengaruh tidak signifikan terhadap kepuasan pelanggan pada Perusahaan Daerah Air Minum (PDAM) Kabupaten Bondowoso (Y). Sehingga, hipotesis yang menyatakan bahwa secara parsial variabel kualitas layanan berbasis Tehnologi Informasi (TI) yang diukur dengan empaty berpengaruh terhadap kepuasan pelanggan pada Perusahaan Daerah Air Minum (PDAM) Kabupaten Bondowoso tidak terbukti kebenarannya atau H2.4 ditolak. 
5. Pengaruh variabel responsiveness (X5) terhadap kepuasan pelanggan (Y) Berdasarkan Tabel 4.3 dapat diketahui bahwa thitung > ttabel yaitu 3,463 > 1,983. Karena thitung lebih besar dari ttabel, maka H0 ditolak, berarti secara parsial variabel responsiveness (X5) mempunyai pengaruh signifikan terhadap kepuasan pelanggan pada Perusahaan Daerah Air Minum (PDAM) Kabupaten Bondowoso (Y). Sehingga, hipotesis yang menyatakan bahwa secara parsial variabel kualitas layanan berbasis Tehnologi Informasi (TI) yang diukur dengan responsiveness berpengaruh terhadap kepuasan pelanggan pada Perusahaan Daerah Air Minum (PDAM) Kabupaten Bondowoso terbukti kebenarannya atau H2.5 diterima.

\subsubsection{Sumbangan Efektif (SE)}

Sumbangan Efektif (SE) merupakan ukuran sumbangan suatu variabel independen terhadap variabel dependen dalam analisis regresi. SE dapat digunakan untuk mengetahui seberapa besar pengaruh faktor-faktor Reliability, Tangible, Assurance, Empaty, dan Responsiveness terhadap kepuasan pelanggan. Hasil perhitungan ini selanjutnya dapat digunakan untuk mengetahui mana diantara variabel independen yang memiliki pengaruh dominan terhadap variabel dependen.

Hasil perhitungan analisis sumbangan efektif (SE) dapat dilihat pada Tabel 4.15

Tabel 4.8 Hasil Perhitungan Regresi Linear Berganda

\begin{tabular}{llccl}
\hline Variabel & Beta & Koefisien Korelasi (r) & SE & $\mathbf{R}^{2}$ atau SE total \\
\hline $\mathrm{X}_{1}$ & 0,282 & 0,689 & $19,4 \%$ & \\
$\mathrm{X}_{2}$ & 0,198 & 0,624 & $12,4 \%$ & \\
$\mathrm{X}_{3}$ & 0,162 & 0,524 & $8,5 \%$ & 0 \\
$\mathrm{X}_{4}$ & 0,097 & 0,619 & $6,0 \%$ & \\
$\mathrm{X}_{5}$ & 0,276 & 0,642 & $17,7 \%$ & \\
\hline
\end{tabular}

Berdasarkan hasil analisis sumbangan efektif (SE) yang bisa dilihat pada

Tabel 4.8 diperoleh hasil bahwa dari kelima variabel independen yang diuji (Reliability, Tangible, Assurance, Empaty, dan Responsiveness), variabel reliability mempunyai nilai SE yang paling besar yaitu 19,4\%. Mengacu pada hasil analisis tersebut, maka dapat dinyatakan bahwa variabel reliability 
merupakan variabel yang dominan dalam mempengaruhi tingkat kepuasan pelanggan di Perusahaan Daerah Air Minum (PDAM) Kabupaten Bondowoso (H3).

\section{Kesimpulan}

Berdasarkan uraian-uraian yang telah diungkapkan pada pembahasan, maka dapat diambil beberapa simpulan sebagai jawaban atas pokok permasalahan yang diajukan dalam penelitian ini, yaitu:

1. Variabel kualitas layanan berbasis Tehnologi Informasi (TI) yang terdiri dari Reliability, Tangible, Assurance, Empaty dan Responsiveness secara simultan berpengaruh terhadap kepuasan pelanggan pada Perusahaan Daerah Air Minum (PDAM) Kabupaten Bondowoso.

2. Variabel kualitas layanan berbasis Tehnologi Informasi (TI) yang terdiri dari Reliability, Tangible, Assurance, dan Responsiveness secara parsial berpengaruh terhadap kepuasan pelanggan pada Perusahaan Daerah Air Minum (PDAM) Kabupaten Bondowoso. Sedangkan variabel kualitas layanan berbasis Tehnologi Informasi (TI) yang diukur dengan Empaty secara parsial berpengaruh tidak signifikan terhadap kepuasan pelanggan pada Perusahaan Daerah Air Minum (PDAM) Kabupaten Bondowoso.

3. Variabel pada kualitas layanan berbasis Tehnologi Informasi (TI) yang diukur dengan reliability merupakan variabel yang dominan dalam mempengaruhi tingkat kepuasan pelanggan di Perusahaan Daerah Air Minum (PDAM) Kabupaten Bondowoso.

\section{Saran}

Dari hasil penelitian ini kiranya peneliti dapat memberikan saran, diantaranya:

1. Perusahaan Daerah Air Minum (PDAM) Kabupaten Bondowoso hendaknya lebih meningkatkan kualitas layanan Reliability, Tangible, Assurance, dan 
Responsiveness, karena kualitas layanan tersebut berpengaruh signifikan terhadap kepuasan pelanggan. Kepuasan pelanggan yang tinggi tentunya akan berdampak pada pencapaian tujuan perusahaan dan dapat mendorong terciptanya konsumen yang loyal serta akan mendorong eksistensi Perusahaan Daerah Air Minum (PDAM) Kabupaten Bondowoso dalam bersaing perusahaan - perusahaan lainnya.

2. Penelitian selanjutnya dapat menggunakan variabel yang lain seperti bauran pemasaran, citra perusahaan, Customer Relationship Management dan lainnya, sehingga diperoleh temuan yang lebih baik dalam menjelaskan perilaku konsumen atau kepuasan pelanggan.

\section{Daftar Pustaka}

Arikunto Suharsimi, 1998, Metode Penelitian Suatu pendekatan Praktek. Edisi Revisi Rineka Cipta, Jakarta

Ali dan Ali, 2016, Pengaruh Kualitas Layanan terhadap Kepuasan Pelanggan Bank Islam, Pakistan

Duwi Priyatno, 2013, Mandiri Belajar Analisis Data dengan SPSS, Mediakom Yogyakarta

Effendi dan Lili, 2016, Pengaruh Kualitas Layanan terhadap Kepuasan Pelanggan JNE, Bandung

Fornell dalam Aryani dan Rosinta, 1992, Kualitas Layanan, Jakarta

Fitzismmons dan Fitzism, 2001, Kepuasan Pelanggan, Jakarta

Hardono, 2014, Pengaruh Kualitas Layanan terhadap Kepuasan Pelanggan Bossanova Billiard, Yogyakarta

Awaludin dan Setiawan, 2012, Pengaruh Kualitas Layanan terhadap Kepuasan Pelanggan PDAM Kota Kendari, Kota Kendari

Julius dan Suhartini, 2015, Pengaruh Kualitas Layanan terhadap Kepuasan Pelanggan PT.Gaido Cito Ekakuribdo, Surabaya

Kotler, Philip. 2002. Manajemen Pemasaran. Edisi Millennium (Terjemahan). Jakarta: Prenhallindo 
Marisniati dan Hadi Wijaya, 2013, Pengaruh Kualitas Layanan terhadap Kepuasan Pelanggan BRT Transmusi, Palembang, Jurnal Vol.3 No.3

Nazir, M. 2003, Metode Penelitian, Ghalia Indonesia, Jakarta

Nur dan Dui, 2013, Pengaruh Kualitas Layanan terhadap Kepuasan Pelanggan Rumah Sakit Banyumas, Banyumas, Jurnal Vol 11 Nomor 2

Parasuman, Zeithami dan Berry, 1998, Communication and Control Procceses in the Delivery of Service Quality, Journal of Marketing vol 52

Purnama, 2014, Strategi Organisasi, Jakarta

Rizan dan Andika, 2017, Pengaruh kualitas produk dan kualitas pelayanan terhadap Kepuasan Pelanggan, Jakarta

Rukayat, 2017, Pelayanan Public, Jakarta

Silvia dan Kartika, 2017, Pengaruh Kualitas Layanan BPJS Kesehatan terhadap Kepuasan Dokter, Bogor

Sugiono, 1999, Metode Penelitian Bisnis, Alfabeta, Bandung

Supranto J, 2001, Pengukuran Tingkat Kepuasan Pelanggan, Rineka Cipta, Jakarta

Sudjana, 2001, Metoda Statistika, Tarsito, Bandung

Syahri dan Rohma, 2017, Pengaruh Kualitas Layanan terhadap Kepuasan Pelanggan di PT. Sucofindo, Batam

Tjiptono, Fandy, 2004, Manajemen Jasa, Andi, Yogyakarta

Tim Penyusun Kamus Pusat Bahasa Departemen Dinas Pendidikan Indonesia, 2008. Kamus Besar Bahasa Indonesia. Edisi keempat, Balai Pustaka, Jakarta

Solang, Mandey, 2014, Kepuasan Pelanggan terhadap Kepuasan Pelanggan PDAM Kota Malugu, Kota Malugu

Utama, 2012, Kepuasan Pelanggan terhadap Kepuasan Pelanggan Rumah Sakit Klaten, Klaten

Wayan dan Ketut, 2015, Kepuasan Pelanggan terhadap Kepuasan Pelanggan Hotel Bintang Pesona, Denpasar Timur 